\title{
Relationship of Antioxidant Enzyme Activities with Myelomeningocele
}

\author{
Myelomeningosel ile Antioksidan Enzim Aktivitelerinin İlişkisi
}

\author{
Mehmet ARSLAN ${ }^{1}$, Mehmet MELEK $^{2}$, Halit DEMIR ${ }^{3}$, Metehan ESEOGLU ${ }^{1}$, Burhan Oral GUDU ${ }^{1}$, \\ Ismail DEMIR ${ }^{1}$, Cigdem $\mathrm{CETIN}^{3}$ \\ ${ }^{1}$ Yuzuncu Yil University, Faculty of Medicine, Department of Neurosurgery, Van, Turkey \\ ${ }^{2} Y u z u n c u$ Yil University, Faculty of Medicine, Department of Pediatric Surgery, Van, Turkey \\ ${ }^{3} Y u z u n c u$ Yil University, Faculty of Medicine, Department of Chemistry, Van, Turkey
}

Correspondence address: Mehmet ARSLAN / E-mail: arslan2002@hotmail.com

\begin{abstract}
AIM: To investigate the role of erythrocyte free radical scavenging enzyme activities (FRSE), carbonic anhydrase (CA) activity and malondialdehyde (MDA) in infants with myelomeningocele (MM).

MATERIAL and METHODS: We compared antioxidant enzyme activities and MDA level in 40 individuals (10 infants with MM, 10 healthy infants; and mothers of these two groups) with age-matched subjects. Erythrocyte FRSE included catalase (CAT), superoxide dismutase (SOD), glutathione peroxidase (GPX) and glutathione-S- transferase (GST).

RESULTS: CA, CAT, SOD, GPX and GST concentrations were lower in all of the infants with MM compared to healthy infants. The mothers of infants with MM also had lower CA, CAT, SOD, GPX and GST activities than healthy mothers. It was also found out that the MDA level as a marker of oxidative damage was higher in infants with $M M$ and their mothers than in healthy infants and their mothers.

CONCLUSION: Lower FRSE activities indicate an increased frequency of MM. Free radicals (FRs) such as MDA may play a significant role in the etiology of MM.

KEYWORDS: Antioxidant enzyme, Mylelomeningocele, Glutathione peroxidase, Glutathione-S-transferase, Superoxide dismutase, Carbonic anhydrase, Catalase
\end{abstract}

\section{Öz}

AMAÇ: Myelomeningoselli çocuklarda eritrosit serbest radikal koruyucu enzim aktiviteleri, karbonik anhidraz (CA) aktivitesi ve malondialdehid (MDA)' in rolünü araştırmak için, antioksidan enzim aktivitelerini ve MDA seviyesini karşılaştırdık.

YÖNTEM ve GEREÇLER: Bu çalışmada, yaş ve cinsiyeti uyumlu 40 bireyde (10 myelomeningoselli çocuk, 10 sağlıklı çocuk ve her iki gruptaki çocukların anneleri) eritrosit serbest radikal koruyucu enzimler olarak katalaz (CAT), süperoksit dismutaz (SOD), glutatyon peroksidaz (GPX) ve glutatyon S-transferaz (GST)'ı kullandık.

BULGULAR: Myelomeningoselli çocuklarda CA, CAT, SOD, GPX and GST seviyeleri sağlıklı çocuklara göre düşük idi. Ayrıca myelomeningoselli çocukların annelerinde CA, CAT, SOD, GPX and GST aktiviteleri sağlıklı çocukların annelerine göre daha düşük bulundu. Bunlara ilave olarak myelomeningoselli çocuklarda ve annelerinde oksidatif harabiyet belirleyicisi olan MDA seviyesi, sağlıklı çocuklar ve annelerinden daha yüksek bulundu.

SONUÇ: Düşük serbest radikal koruyucu enzim aktiviteleri myelomeningoselin artmış insidansı ile birlikteydi. Ayrıca MDA gibi serbest radikaller myelomeningoselin etiyolojisinde önemli rol oynayabilir.

ANAHTAR SÖZCÜKLER: Antioksidan enzim, Myelomeningosel, Glutathione peroxidase, Glutathione-S-transferase, Superoxide dismutase, Carbonic anhydrase, Catalase

\section{INTRODUCTION}

Myelomeningocele $(\mathrm{MM})$ is a common congenital malformation that occurs when the embryonic neural tube fails to close properly during early embryogenesis. Considerable advances have been made regarding the etiology of MM. The common mechanisms for MM include folate deficiency, genetic susceptibility, environmental factors, in utero drug exposure and biochemical factors $(2,5,20,21,22$, 29). Numerous reports have described free radicals (FRs)- mediated congenital defects $(2,3,12,18,22,26)$. Under normal physiological conditions, FRs are quickly destroyed by antioxidant defense systems. However, FR-mediated cellular damage can occur if there is a genetic deficiency in free radical scavenging enzyme (FRSE) activity (22). Evidences that have been presented so far suggest that an imbalance between diminished host antioxidant defenses and increased formation of FRs creates a state of oxidative stress (12, $16,20,22,25)$. FRs play a crucial role in MM and there is a direct relationship between antioxidant enzymes and the 
development of MM $(21,22)$. However, to our knowledge, little attention has been given to this important detoxicating and scavenging system in the etiology and pathophysiology of MM. In this paper, we reviewed the antioxidant enzymes and malondialdehyde (MDA), that lead to oxidative damage, in MM. We briefly discussed the roles of free radicals and antioxidant enzymes in MM.

\section{MATERIAL and METHODS}

We analyzed 10 infants with MM, 10 healthy infants and 20 mothers of these two groups. Infants with MM underwent MM sac repair at our institution (Neurosurgery Clinic of Yuzuncu Yil University). Anomalies outside the central nervous system, such as esophageal atresia, intestinal atresia and congenital heart disease, were excluded from our study. Central nervous system anomalies which are seen together with myelomeningocele, such as syringomyelia and chiari malformations, are included into the study but they were not analysed as sub-groups and are only assessed under the title of myelomeningocele. Healthy individuals without any chronic disease were included as a control group. Information about the individuals' condition was gathered. The gender types were recorded (5 girls, 5 boys for each infant group). The infants' ages ranged from 1 day to 4 days. Age- and sexmatched healthy infants were included in the study as a control group. All mothers and newborns who were involved in the study were examined in detail; clinical examination, routine laboratory investigations and imaging studies were performed. MDA and antioxidant enzymes were investigated for each group. The cases were classified into four groups as Group I: the infants with MM; Group 2: the healthy infants; Group 3: mothers of the infants with MM; Group 4: mothers of healthy infants. The study was approved by the local ethics committee. Consent was given by family members of all the patients involved in this study.

\section{Biochemical Analysis}

Biochemical analysis was performed by the Biochemistry Laboratory of the Chemistry Department, Faculty of Science, Yuzuncu Yil University. The venous blood samples of infants and adult individuals were obtained from the antecubital fossa vein in accordance with the guidelines mentioned in the Declaration of Helsinki. If the infant was born in our hospital, a blood specimen was taken as soon as infant was born. If the child was referred to our hospital from another centre, the blood specimen was taken at the time the child arrived at our hospital. The ages of infants ranged from 1 day to 4 days at the time of taking the blood specimen and all the blood specimens were taken before the repair of the MM sac. Fasting blood samples were obtained from all subjects and collected into tubes with coagulant. Serum was separated by centrifugation (serum was obtained by centrifugation at $2500 \mathrm{rpm}$ for 15 minutes) and the samples were processed immediately. The serum samples were placed in deionized polyethylene tubes and kept at $-80^{\circ} \mathrm{C}$ in a deep-freeze (without thawing) until the day of study. The whole blood MDA levels were determined as oxidative stress markers. Activities of carbonic anhydrase (CA), catalase (CAT), superoxide dismutase (SOD), glutathione peroxidase (GPX) and glutathione -S- transferase (GST) in erythrocytes were also measured as markers of the antioxidant system. Red blood cells, separated from serum, were washed three times with cold physiological saline and with demineralized water prior to analysis of hemoglobin and enzyme activities.

The antioxidant enzyme activities were assayed by using previously mentioned methods. MDA was estimated by measuring TBARS in whole-blood samples according to a modified method of Jentzsch et al. (13). Briefly, $0.2 \mathrm{ml}$ of whole-blood was added to the reaction mixture containing $1 \mathrm{ml}$ of $1 \%$ ortho-phosphoric acid, $0.25 \mathrm{ml}$ alkaline solution of thiobarbituric acid-TBA (final volume $2.0 \mathrm{ml}$ ) followed by 45 min heating at $95^{\circ} \mathrm{C}$. The results were expressed as nmol MDA per milliliter of plasma. CA activity was assayed by hydration of $\mathrm{CO}_{2}$ in erythrocytes. Hydration of $\mathrm{CO}_{2}$ was measured by the method of Rickli and Wilbur-Anderson with bromothymol blue as an indicator (23). Enzyme activity was measured on the basis of a $\mathrm{pH}$ dependent colour change occurring as $\mathrm{CO}_{2}$ is hydrated to bicarbonate and hydrogen ions in the presence of veronal buffer and bromthymol blue. A colorimetric technique was applied for the determination of CA activity. Biochemical analysis of CAT activity in erythrocytes was carried out with a method described by Aebi (1). Briefly, the supernatant $(0.1 \mathrm{ml})$ was added to a quartz cuvette containing $2.95 \mathrm{ml}$ of $19 \mathrm{mmol} \mathrm{l}^{-1} \mathrm{H}_{2} \mathrm{O}_{2}$ solution prepared in potassium phosphate buffer $(0.05 \mathrm{M}, \mathrm{pH} 7.00)$. The change in absorbance was monitored at $240 \mathrm{~nm}$ for 5 min using a spectrophotometer (Shimadzu UV-1201, Japan). SOD was measured spectrophotometrically according to the GSH-400 and SOD-525 methods and assay conditions developed by Bioxytech S.A. Company (Cedex, France). SOD activation was measured with Randox-Ransod enzyme kit with autoanalyzer at $505 \mathrm{~nm}$ and $37{ }^{\circ} \mathrm{C}$. It was determined in red blood cell. $0.1 \mathrm{ml}$ of blood was hemolyzed by $0.9 \mathrm{ml}$ of ice cold water $\left(0-4{ }^{\circ} \mathrm{C}\right)$. The hemoglobin was removed by adding $0.25 \mathrm{ml}$ of chloroform and $0.5 \mathrm{ml}$ of ethanol followed by vigorous mixing and then mixture was centrifuged at 18,000 for $60 \mathrm{~min}$. The rate of inhibition of the superoxide reaction by SOD was calculated according to the definition of McCord and Fridovich (17). GPX enzyme activity was measured with commercial kits in a DU-640 spectrophotometer (Beckman Instruments, California, USA). GPx activities were spectrophotometrically assayed in erythrocytes GPX (19). GPX activity was measured in erythrocyte by using a Hitachi 902 Autoanalyzer (Hitachi, Brisbane, CA) with Randox's reagent (San Diego, CA). Results were indicated per milliliter of whole blood. When the oxide glutathion is reduced, NADPH is oxidized and it is turned into NADP. This change was observed at $340 \mathrm{~nm}$ wave and activation of GPx was measured. The intra-assay and inter assay CV for GPx were $5.2 \%$ and $7.2 \%$, respectively. Units of GPx activity were calculated following NADPH oxidation at $340 \mathrm{~nm}$ using cumene hydroperoxide as the substrate. Glutathione S transferase activity was determined according to Habig et al.(11). 


\section{Statistical Analysis}

Statistical comparison among groups in terms of antioxidant enzyme activities and MDA were evaluated by using the Mann-Whitney $U$ test. $<0.05$ was considered statistically significant. Descriptive statistics for data were presented as mean, standard deviation, minimum and maximum values. All statistical analyses were carried out via using statistical analysis program (SPSS 13.0 for Windows).

\section{RESULTS}

Whole blood MDA as a marker of oxidative damage, CA level and FRSE (CAT, SOD, GPX and GST) activities were assessed in 40 individuals in total consisting of 10 patients with myelomeningocele, 10 healthy infants as control group and 20 mothers of these both groups. The mean whole blood MDA concentration for infants with MM (2.81) and for their mothers (3.090) was higher than the mean of healthy infants (1.284) and for the mothers of healthy ones (1.65). Erythrocyte CA activity was found to be lower in patient groups than in control groups. Erythrocyte CA activity was 0.239 in infants with MM, 0.88 in healthy infants; 0.780 in mothers of infants with MM and 1.340 in mothers of healthy infants. There were statistically meaningful differences between patient and control groups in terms of MDA and CA. $(p<0.05)$. All of infants with MM had significantly lower erythrocyte FRSE activities (CAT, SOD, GPX, GST) than the healthy infants. In the infants with MM, the mean erythrocyte CAT, SOD, GPX and GST activities were $0.406,15.484,31.726$ and 2.064 , respectively; while in infants of the control group, erythrocyte FRSE activities were 1.309, $20.234,45.744$ and 3.25 , respectively. There were statistically significant differences between infants with MM and healthy ones $(p<0.05)$. In mothers of infants with MM, the CAT, SOD, GPX and GST activities were 0.936, 7.311, 37.25 and 0.932, respectively; however, in the control mothers' group, CAT, SOD, GPX and GST values were 2.40, 7.253, 41.14 and 2.284, respectively. FRSE activities were found to be lower in the patient's mothers group when compared to control mothers group. FRSE activity differences were statistically meaningful between mothers with MM and in mothers who were healthy except for SOD and GPX $(p<0.05)$. The results are shown in Table I.

\section{DISCUSSION}

MM is a congenital anomaly that involves failure of the neural tube closure during embryogenesis and this defect may occur at any stage during the formation of the spinal cord $(21,22)$. Oxygen-derived FRs are important factors in the pathogenesis of many pediatric neurological diseases $(6,7,10,24)$. Numerous studies have shown the relationship between FRs and neural tube defects $(7,8,9,10,20,29)$. The antiepileptic drugs producing FRs increase FR-mediated cellular damage and may result in neural tube defects ( 8 , $21,25,27)$. Exposure of rat embryos to a high concentration of oxygen (20\%) during early neurulation (day 9 to 10 ) significantly increased the incidence of neural tube defects when compared with control embryos (12). Other studies have reported that reactive oxygen species can cause protein, RNA or DNA damage and apoptosis $(12,18,28)$.

The body possesses a variety of defense systems to protect cells from FR damage. One of those antioxidant defense mechanisms include antioxidant enzymes (FRSE): CAT, SOD, GPX and GST $(6,21,26)$. These enzymes play an active role in the detoxification of $\mathrm{H}_{2} \mathrm{O}_{2}$ for the protection of cell against oxidative stress. The impaired responsiveness of the FRSE system plays a crucial role in oxygen-induced embryopathy and might result in $M M(7,8,9,10,12,15,21)$. Erythrocyte FRSE are the most important enzymes in prevention of FRmediated neurological disease (6). When FR damage occurs, cellular repair systems such as GPX and GST can restore cellular components to their normal structure and function (21). GPX, GST and SOD enzymes are the most important protective systems in humans for neural tube defects and for the antioxidant defense system $(7,10,15,21)$. In addition, SOD is an important enzyme in the pathophysiology of FRmediated neurological diseases and plays a fundamental role in modulating reactive oxygen species toxicity $(4,12$, $15,17,21)$. In tissues lacking significant catalase activity, detoxification of hydrogen peroxidase becomes critically dependent on GPX (12).

Only a few articles describing abnormal FRSE activities in infants with $\mathrm{MM}$ have been published $(6,7,8,10)$. Previous studies measured FRSE activities, especially GSH-related

Table I: MDA and Antioxidant Enzyme Activities in Erythrocytes and in Infants with Myelomeningocele, Control Subjects and Their Mothers

\begin{tabular}{|c|c|c|c|c|c|c|c|c|}
\hline & \multicolumn{2}{|c|}{ Infants with MM } & \multicolumn{2}{|c|}{ Healthy infants } & \multicolumn{2}{|c|}{$\begin{array}{c}\text { Mothers of infants } \\
\text { with MM }\end{array}$} & \multicolumn{2}{|c|}{$\begin{array}{l}\text { Mothers of healthy } \\
\text { infants }\end{array}$} \\
\hline & Mean \pm SD & Range & Mean \pm SD & Range & Mean \pm SD & Range & Mean \pm SD & Range \\
\hline MDA ( $\mu \mathrm{mol} / \mathrm{L})$ & $2.81 \pm 0.20$ & $2.49-3.21$ & $1.284 \pm 0.23$ & $1.019-1.915$ & $3.090 \pm 0.14$ & $2.99-3.41$ & $1.651 \pm 0.10$ & $1.56-1.91$ \\
\hline CA EU/(gHb)-1 & $0.239 \pm 0.1$ & $0.109-0.419$ & $0.883 \pm 0.07$ & $0.789-0.995$ & $0.780 \pm 0.0$ & $0.619-0.897$ & $1.340 \pm 0.53$ & $0.695-1.933$ \\
\hline CAT EU/(gHb)-1 & $0.406 \pm 0.19$ & $0.09-0.68$ & $1.309 \pm 0.15$ & $1.021-1.481$ & $0.936 \pm 0.11$ & $0.763-1.11$ & $2.401 \pm 0.28$ & $1.815-2.767$ \\
\hline SOD (EU/ mL) & $15.484 \pm 0.80$ & $14.06-17.00$ & $20.234 \pm 0.46$ & $19.45-20.77$ & $7.311 \pm 0.37$ & $6.471-7.777$ & $7.253 \pm 0.41$ & $6.541-7.81$ \\
\hline GPX (EU/ mL) & $31.726 \pm 3.01$ & $27.09-35.06$ & $45.744 \pm 1.90$ & $41.02-47.25$ & $37.25 \pm 1.06$ & $36.44-40.21$ & $41.14 \pm 0.74$ & $40-42.31$ \\
\hline GST (EU/L) & $2.064 \pm 0.25$ & $1.81-2.71$ & $3.25 \pm 0.23$ & $3.01-3.77$ & $0.932 \pm 0.66$ & $0.099-1.92$ & $2.284 \pm 0.21$ & $2.08-2.75$ \\
\hline
\end{tabular}


enzymes. We added MDA as an oxidative damage marker and CA as antioxidant. In the study of Graf and colleagues (10) in 26 children, the FRSE activity was compared between the MM group and control group. GPX, glutathione reductase, GST, CAT, and SOD activities were determined. Children of families who had more than one child with a MM had significantly lower GPX activity, and children with MM had abnormal FRSC as well as significantly lower GPX activity. Both the mothers and fathers of those patients also had significantly low GPX and activity, suggesting a genetic link between parents and children predisposing to low FRSC $(10,21)$. In another study by Graf et al., FRSE activities were measured in $37 \mathrm{MM}$ children classified according to the level of their MM sac. There was significantly lower GPX activity in children with MM (7). The studies of Graf et al. $(7,10,21)$ indicated that deficiencies of GPX are directly linked to neural tube defects. More recently, Graf and colleagues have demonstrated that GPX can be depressed in valporoic acid-treated patients (8).

We found in this study that the MDA level as a marker of oxidative damage was higher in newborns with $\mathrm{MM}$ and in their mothers than in healthy newborns and in their mothers. This indicated that increased lipid peroxidation might also play an important role in the pathogenesis of MM. The oxidative stress that is seen during pregnancy in the mother may potentially affect the child badly. However, when compared to the healthy group, the higher MDA levels of MM infants may be considered as proof of inadequate antioxidant mechanisms protecting from oxidative stress under some circumstances.

CA plays different roles in various tissues (23). CA is the key enzyme that regulates the acid-base homeostasis in both normal and pathological conditions. In this study, it was found out that the CA enzyme activity was lower in newborns with $\mathrm{MM}$ and in their mothers than in healthy newborns and in their mothers. It was also found that CA enzyme activity in healthy newborns was statistically different from newborns with MM. The increased CA activity might be considered as an evidence of acid-base imbalance in these patients. These findings indicate that the CA enzyme has an important role in the elimination of oxidative stress.

We also found that the CAT, SOD, GPX and GST enzyme activities were significantly lower in infants with MM and in their mothers than in the healthy infants and in their mothers. All infants with MM had deficiencies in erythrocyte FRSE activities. The differences identified in FRSE activities were consistent with the results indicated in the literature $(6,7,10$, 12). Graff et al. (7) found that there were significant differences between patient and control groups. FRSE activities (CAT, GPX, SOD and GST) and especially GPX in children with MM was significantly lower when compared to healthy ones. The study of Glauser et al. (6) found that the differences between healthy and ill children were noteworthy and associated with changes in their FRSE activities. Their results indicate that healthy children have better enzymatic FRSE ability than the children with MM (6). Ishibashi and Akazawa (12) have reported a similar observation. They found an extremely low catalase activity in the rat embryo during the organogenetic period.

When the lower FRSE activities of the mothers and the babies in the patient group are compared to the healthy group, it can be concluded that low antioxidant enzyme levels of the mothers of the patient group were transmitted to their babies and this insufficiency in enzyme levels plays an important role in insufficiency of oxidative stress-coping mechanisms of the newborns.

There are some conflicts between results. Verrotti et al. (27) reviewed the relationship of FRSE activity with neural tube defects and stated that there were no significant changes in GPX and CuZn-SOD activities between MM and control groups. Conflicting reports by Hinks et al. (15) were published in relation with erythrocyte GPX activities of parents of children with neural tube defects. They did not find a difference in maternal whole blood GPX activities during pregnancy in women bearing babies with neural tube defects when compared with women with uncomplicated pregnancies (15). Graf et al. did not find a low erythrocyte GPX activity in the majority of the parents of children with a neural tube defect. In our study, there were significant differences between the mothers of the patients and the control mothers group except for SOD and GPX $(p<0.05)$.

Authors $(14,18)$ studying the levels of various antioxidant enzymes and studies on rat embryos and in rabbit fetuses found a gradual increase in the activity of most enzymes. In addition, multiple studies have demonstrated that the genetic susceptibility plays a key role in $\operatorname{MM}(2,5,20,21)$. Patients with genetically low FRSE activity are more susceptible to FRinduced damage (21). In this study, decreased FRSE activity in the mothers of infants with MM suggests a genetic link.

We believe that impaired responsiveness of the antioxidant system against oxidative stress during embryogenesis may play an important role in MM. Low antioxidant enzyme levels in our patients with myelomeningocele may indicate a role for abnormal oxidative metabolism in the development of this defect. Also, MM that is FR-mediated can be attributed to an increased FRs and decreased FRSE activity in the developing embryo. Many studies have demonstrated that antioxidants can prevent congenital malformations $(2,20)$. Recent studies have shown that the addition of SOD or antioxidants to diet in culture helps to reduce the rate of embryonic anomalies (26).

The low antioxidant enzyme activity in mothers of infants with MM in this study indicates that following the antioxidant enzyme activities in addition to using ultrasound and acetylcholine esterase (in amniotic fluid) and maternal serum alpha fetoprotein (in serum or in the amniotic fluid) in risky pregnancies may be useful methods to check an overt neural tube defect. In pregnant women with low antioxidant enzyme activities, giving antioxidant enzymes together with folic acid may be unlikely to reduce the incidence of neural tube defect but this is only a theory and more detailed studies are needed on this issue. 
In conclusion, increased oxidative stress and insufficient free radical protective enzyme activities may play a role in the etiology of myelomeningocele in addition to genetic, environmental and metabolic factors.

\section{REFERENCES}

1. Aebi H: Catalase. In: L. Packer(Ed), methods in enzymology, Orlando: Academic Press, 1984:105:121-126

2. Chang $\mathrm{TI}$, Horal M, Jain SK, Wang F, Patel R, Loeken MR: Oxidant regulation of gene expression and neural tube development: Insights gained from diabetic pregnancy on molecular causes of neural tube defects. Diabetologia 46:538-545, 2003

3. El-Hage S, Singh SM: Temporal expression of genes encoding free radical-metabolizing enzymes is associated with higher mRNA levels during in utero development in mice. Dev Genet 11:149-159, 1990

4. Gaeta LM, Tozzi G, Pastore A, FedericiG, Bertini E, Piemonte F: Determination of superoxide dismutase and glutathione peroxidase activities in blood of healthy pediatric subjects. Clinica Chimica Acta 322:117-120, 2002

5. Gelineau-van Waes J, Finnell RH: Genetics of neural tube defects. Semin Pediatr Neurol 8:160-164, 2001

6. GlauserTA, Titanic-Schefft M, Pippenger CE: Racial differences in free radical scavenging enzyme activity in children. J Child Neurol 14: 382-387, 1999

7. Graf WD, Oleinik OE, Pippenger CE, Eder DN, Glauser TA, Shurtleff DB: Comparison of erythrocyte antioxidant enzyme activities and embryologic level of neural tube defects. Eur J Pediatr Surg 1:8-11, 1995

8. Graf WD, Oleinik OE, Glauser TA, Maertens P, Eder DN, Pippenger CE: Altered antioxidant enzyme activities in children with a serious adverse experience related to valproic acid therapy. Neuropediatrics 29:195-201, 1998

9. Graf WD, Oleinik OE, Jack RM, Eder DN, Shurtleff DB: Plasma homocysteine and methionine concentrations in children with neural tube defects. Eur J Pediatr Surg 6 Suppl 1:7-9, 1996

10. Graf WD, Pippenger CE, Shurtleff DB: Erythrocyte antioxidant enzyme activities in children with myelomeningocele. Dev Med Child Neurol 37: 900-905, 1995

11. Habig WH, Pabst MJ, Jakoby WB: Glutathione-S-transferases: The first enzymatic step in mercapturic acid formation. J Biol Chem 249:7130-7139, 1974

12. Ishibashia $M$, Akazawaa $S$, Sakamakia $H$, Matsumotoa $K$, Yamasakia H, YamaguchiaY, Gotob S, Uratab Y, Kondob T, Nagatakia S: Oxygen-Induced embryopathy and the significance of glutathione-dependent antioxidant system in the rat embryo during early organogenesis. Free Radical Biology and Medicine 22:447-454, 1997

13. Jentzsch AM, Bachmann H, Furst P, Biesalski HK: Improved analysis of malondialdehyde in human body fluids. Free Radic Biol Med 20:251-256, 1996

14. Khan JY, Black SM: Developmental changes in murine brain antioxidant enzymes. Pediatr Res 54:77-82, 2003
15. Knapena MF, Zusterzeel PL, Peters WH, Steegers EA: Glutathione and glutathione-related enzymes in reproduction. A review. Eur J Obstet Gynecol Reprod Biol 82: 171-184, 1999

16. Look MP, Rockstroh JK, Rao GS, Kreuzer KA, Barton S, Lemoch $\mathrm{H}$, Sudhop T, Hoch J, Stockinger K, Spengler U, Sauerbruch T: Serum selenium, plasma glutathione (GSH) and erythrocyte glutathione peroxidase (GSH-Px)-levels in asymptomatic versus symptomatic human immunodeficiency virus-1 (HIV1)-infection. Eur J Clin Nutr 51:266-272, 1997

17. McCord J M, Fridovich I: Superoxide dismutase: An enzymic function for erythrocuprein (hemocuprein). J Biol Chem 244:6049-6055, 1969

18. Ornay A: Embryonic oxidative stress as a mechanism of teratogenesis with special emphasis on diabetic embryopathy. Reprod Toxicol 24:31-41, 2007

19. Paglia De, Valentıne WN: Studies on the quantitative and qualitative characterisation of erytrocyte glutahione peroxidase. J Lab Clin Med 70:158-159, 1967

20. Pani L, Horal M, Loeken M R: Polymorphic susceptibility to the molecular causes of neural tube defects during diabetic embryopathy. Diabetes 51:2871-2874, 2002

21. Pippenger CE: Pharmacology of neural tube defects. Epilepsia 44: 24-32, 2003

22. Finnell RH, Gould A, Spiegelstein O: Pathobiology and Genetics of Neural Tube Defects. Epilepsia 44:14-23, 2003

23. Rickli EE, Ghazanfar SA, Gibbons BH, Edsall, JT: Carbonic anhydrases from human erythrocytes: Preparation and properties of two enzymes. J Biol Chem 239:1065-1078, 1964

24. Stephensen CB, Marquis GS, Douglas SD, Kruzich LA, Wilson CM: Glutathione, glutathione peroxidase, and selenium status in HIV-positive and HIV-negative adolescents and young adults. Nutrition 85:173-181, 2007

25. Weber G F, Maertens P, Meng XZ, Pippenger CE: Glutathione peroxidase deficiency and childhood seizures. Lancet 15 : 1443-1444, 1991

26. Weksler-Zangen S, Yaffe P, Ornoy A: Reduced SOD activity and increased neural tube defects in embryos of the sensitive but not of the resistant Cohen diabetic rats cultured under diabetic conditions. Birth Defects Research Part A: Clinical and Molecular Teratology 67: 429-437, 2003

27. Verrotti A, Basciani F, Trotta D, Pomilio MP, Morgese G, Chiarelli F: Serum copper, zinc, selenium, glutathione peroxidase and superoxide dismutase levels in epileptic children before and after 1 year of sodium valproate and carbamazepine therapy. Epilepsy Research 48:71-75, 2002

28. Zhao H, Liang J, Li X, Yu H, Li X, Xiao R: Folic acid and soybean isoflavone combined supplementation protects the post-neural tube closure defects of rodents induced by cyclophosphamide in vivo and in vitro. NeuroToxicology 31:180-187, 2010

29. Zhao W, Mosley BS, Cleves MA, Melnyk S, James SJ, Hobbs CA: Neural tube defects and maternal biomarkers of folate, homocysteine, and glutathione metabolism. Birth Defects Res A Clin Mol Teratol 76: 230-236, 2006 